О. Міхно // Наукові записки [Кіровоградського державного педагогічного університету ім. Володимира Винниченка]. - 2013. - Вип. 123 (1). - С. 228-233. (Серія «Педагогічні науки»).

5. Міхно О. П. Психологічний семінар В. Сухомлинського та його роль у вивченні особистості учня / О. П. Міхно // Науковий вісник Миколаївського державного університету ім. В. О. Сухомлинського. 2014. - Вип. 1.46. - С. 89-97. - (Серія «Педагогічні науки»).

6. Нова українська школа. Концептуальні засади реформування середньої школи [Електронний реcypc]. URL : http://mon.gov.ua/\%D0\%9D\%D0\%BE\% D0\%B2\%D0\%B8\%D0\%BD\%D0\%B8\%202016/12/05/ konczepcziya.pdf (дата звернення: 01.08.2019).

7. «Обережно: дитина!»: В. О. Сухомлинський про важких дітей : тематич. зб. / упор. Т. В. Філімонова ; за ред. О. В. Сухомлинської. - Луганськ : Луганський нац. ун-т ім. Т. Шевченка, 2008. - С. 214-224.

8. Петренко О. Б. Творче використання досвіду В. Сухомлинського в сучасній сімейно-родинній $\mathrm{i}$ шкільній практиці / О.Б.Петренко // Оновлення змісту, форм та методів навчання і виховання в закладах освіти : зб. наук. пр. Рівнен. держ. гуманітар. ун-ту. Рівне, 2001. - Вип. 17. - С. 118-125.

9. Професійний стандарт «Вчитель початкових класів закладу середньої освіти» [Електронний pecypc]. URL: https://zakon.rada.gov.ua/rada/show/ v1143732-18 (дата звернення: 02.08.2019).

10. Стандарт вищої освіти [Електронний ресурс]. URL: https://mon.gov.ua/storage/app/media/vyshcha/ naukovo-metodychna_rada/proekty_standartiv VO/013-pochatkova-osvita-bakalavr-21.09.7.doc (дата звернення: 01.08.2019).
11. Сухомлинская О. В. Идеи и свершения Василия Александровича Сухомлинского (1918 -1970) / О. В. Сухомлинская // Советская педагогика. - 1988. № 9. - C. 11-17.

12. Сухомлинский В. А. Что такое добро и зло / В. А. Сухомлинский // Свободное воспитание. - М. : ВЛАДИ, 1993. - Вып. 3. - С. 2-8.

13. Сухомлинська О. В. Школа Сухомлинського у Павлиші - погляд крізь призму часу : науково-популярне видання / О. В. Сухомлинська. - К. : Педагогічна думка, 2013. - 124 с.

14. Сухомлинський В. О. Думки про шкільне виховання / В. О. Сухомлинський // Вибр. тв. : в 5 т. - К. : Рад. шк., 1976. - Т. 5. - С. 378-392.

15. Сухомлинський В. О. Духовний світ школяра / В. О. Сухомлинський // Вибр. тв. : в 5 т. - К. : Рад. шк., 1976 . - Т. 1. - С. 209-400.

16. Сухомлинський В. О. Людина неповторна / В. О. Сухомлинський // Вибр. тв. : в 5 т. - К. : Рад. шк., 1976. - Т. 5. - С. 80-96.

17. Сухомлинський В. О. На нашій совісті - людина / В. О. Сухомлинський // Вибр. тв. : в 5 т. - К. : Рад. шк., 1976. - Т. 5. - С. 203-217.

18. Сухомлинський В. О. Розмова з молодим директором школи / В. О. Сухомлинський // Вибр. тв. : в 5 т. - К. : Рад. шк., 1976. - Т. 4. - С. 393-629.

19. Сухомлинський В. О. Серце віддаю дітям / В. О. Сухомлинський // Вибр. тв. : в 5 т. - К. : Рад. шк., 1976. - Т. 3. - С. 7-282.

20. Сухомлинський В. О. Сто порад учителеві / В. О. Сухомлинський // Вибр. тв. : в 5 т. - К. : Рад. шк., 1976. - Т. 2. - С. 419-655.

Дата надходження до редакиії: 06.08.2019 р.

\title{
ПСИХОЛОГО-ПЕДАГОГІЧНІ УМОВИ РОЗУМОВОГО ВИХОВАННЯ ДІТЕЙ У ПРАЦЯХ В. О. СУХОМЛИНСЬКОГО
}

\begin{abstract}
У статті визначені та охарактеризовані психолого-педагогічні умови розумового виховання дітей у прачях В. О. Сухомлинського, які є актуальними для сучасної освіти. Психолого-педагогічні умови включають сукупність об 'єктивних можливостей змісту, форм, методів, прийомів і засобів педагогічної діяльності, шио грунтуються на закономірностях розвитку особистості дитини, створенні психологічно комфортного та безпечного середовища.

Ключові слова: розумове виховання, інтелектуальна прачя, психолого-педагогічні умови, заклад освіти.
\end{abstract}

В статье определены и охарактеризованы психолого-педагогические условия умственного воспитания детей в трудах В. А. Сухомлинского, которые актуальны для современного образования. Психолого-педагогические условия включают совокупность объективных возможностей содержания, форм, методов, приемов и средств педагогической деятельности, основанные на закономерностях развития личности ребенка, создании психологически комфортной и безопасной среды.

Ключевые слова: умственное воспитание, интеллектуальный труд, психолого-педагогические условия, учебное заведение. 
The article analyzes the scientists views on the relevance of the pedagogical heritage of $V$. O. Sukhomlynsky in the implementation of the New Ukrainian School concept: the principles of child-centeredness and nature-compliance; components of the pedagogical system - the deep psychologization of an educational process, the organization of various types of children activity, development of their emotional intelligence, the humanistic relationships in pedagogical and student groups, the creation of a developing environment, etc. The views of $V$. O. Sukhomlinsky about the concept of «mental education», features of adults and children mental work, unity of child intellectual and emotional development, research character of mental activity are analyzed.

The psychological and pedagogical conditions of children mental education in the works of $V$. O. Sukhomlynsky, which are relevant for modern education, are determined and described. Psychological-pedagogical conditions include a set of objective possibilities, forms and methods of pedagogical activity, based on the development laws of the child's personality, creating a psychologically comfortable and safe environment.

The determined psychological and pedagogical conditions are aimed at ensuring the effective mental development process of the child: the consideration of the laws of mental development of the person, psychophysiological mechanisms of human thinking, age characteristics of children, phased thinking development of the child from figurative to abstract, creating psychological comfort, observance of the culture of mental work, organization of interaction between child, nature and society on the basis of research activities, education of children personal qualities, which will promote their mental development, the development of cognitive motivation and child's curiosity, the creation of an intellectual environment, the implementation of the appointment of an educational institution - to teach the child to study.

Key words: mental education, intellectual work, psychological and pedagogical conditions, educational institution.

Актуальність теми. Своєю педагогічною та літературною працею В. О. Сухомлинський утверджував величезну роль педагогіки в розвитку мислення учнів, їхнього інтелекту. Він зауважував, що «ми живемо в час, коли без оволодіння науковими знаннями неможливі ні праця, ні елементарна культура людських відносин, ні виконання громадянського обов'язку» [8, с. 14]. Ця теза не перестає бути актуальною в сучасному суспільстві, яке характеризується надзвичайною мінливістю, швидким темпом розвитку технологій. У працях педагога та науковця ми знаходимо відповіді на складні питання, які висуває час реформ. Визначаючи наукові засади, на яких грунтувалася педагогічна система В. О. Сухомлинського, О. Я. Савченко зауважує актуальність і затребуваність цих ідей у сучасній початковій школі. Зокрема, в методології Нової української школи базовими принципами є дитиноцентризм і природовідповідність, що визначає дитину центром освітнього процесу. Це відображено в багатьох творах ученого, наприклад: «Серце віддаю дітям», «Сто порад учителю», «Розмова 3 молодим директором школи» тощо. Зважаючи на це, метою закладу освіти $є$ створення найкращих умов для всебічного розвитку особистості дитини. Цьому, на думку О. Я. Савченко, сприяє глибоко продумана психологізація освітнього процесу, організація різних видів активностей дітей, розвиток їх емоційного інтелекту, гуманістичні взаємовідносини в педагогічному та учнівському колективах тощо [6].

Аналіз наукових досліджень і публікацій. У сучасній психолого-педагогічній науці немає одно-значного тлумачення поняття «розумове виховання»: дослідники по-різному визначають його зміст, зважаючи на власні наукові позиції. В енциклопедичному словнику С. У. Гончаренка означений термін пов'язується з розвитком мислення й пізнавальними здібностями людини [2, с. 406]. О. С. Падалка, здійснивши контент-аналіз поняття, визначає його як цілеспрямовану діяльність педагогів із розвитку розумових сил і мислення учнів, прищеплення їм культури розумової праці [4, с. 84].

У своїх працях В. О. Сухомлинський, розкриваючи суть розумового виховання школярів, послуговувався поняттями «інтелектуальна праця», «розумова праця». Визначаючи сенс інтелектуальної праці, педагог акцентує увагу на спрямованості розумових зусиль, проникненні в різноманітні «складнощі i тонкощі, деталі і протиріччя речей, фактів, явищ» [8, с. 108-109]. Він звертає увагу на відмінності розумової праці дітей від розумової праці дорослої людини, які полягають у тому, що «для дитини кінцевий результат оволодіння знаннями не може бути головним стимулом іiі розумових зусиль, як у дорослого. Джерело бажання вчитися - в емоційному забарвленні думки, в інтелектуальних переживаннях». Педагог стверджує, що «дитина не повинна вчитися заради оцінки, а з бажання пережити хвилююче інтелектуальне почуття» $[8$, с. 65,117$]$. Педагог наголошував, що «розумове виховання починається там, де $\epsilon$ теоретичне мислення, де живе споглядання не кінцева ціль, а лише засіб: яскравий образ навколишнього світу є для вчителя джерелом, у різних формах, фарбах, звуках якого приховані тисячі запитань» [8, с. 126]. Він чітко розмежовує поняття «розумове виховання» та «освіта», вказуючи на те, що розумове виховання не зводиться до набуття знань чи освіти, хоча тісно пов'язане з ними.

Н. Калініченко вказує на актуальність ідей великого педагога щодо розумового виховання дітей: забезпечення дослідницького характеру розумової праці учнів, необхідність навчання їх мистецтву мислення; вибір та оптимальне поєднання методів навчання; створення окремої програми інтелектуального розвитку обдарованих дітей; створення інтелектуального середовища тощо [3, с. 18]. Наукове осмислення досвіду роботи В. О. Сухомлинського в Павлиській школі дозволило О. Я. Савченко визначити складові методики розумового виховання дітей: постановка вчителем перспективних цілей розвитку мислення i творчих здібностей учнів; досягнення тісного взаємозв'язку мовленнєвої, розумової та трудової діяльності молодших школярів; проведення уроків мислення на природі; творчі роботи з розвитку мовлення; стимулювання інтелектуальних та естетичних почуттів дитини [5, с. 220].

Мета статті - визначити та охарактеризувати психолого-педагогічні умови розумового виховання дітей у працях В. О. Сухомлинського, які є актуальними для сучасного етапу реформування освіти. 
Виклад основного матеріалу. Як зазначається у довідниковій літературі, умова - це «необхідні обставини, особливості реальної дійсності, які уможливлюють здійснення, створення, утворення чого-небудь або сприяють чомусь» [1, с. 1295]. Дослідники визначають різні види умов: організаційні, психологічні, соціальні, педагогічні тощо. Окреслені нами психолого-педагогічні умови включають сукупність об'єктивних можливостей змісту, форм, методів, прийомів і засобів педагогічної діяльності, що грунтуються на закономірностях розвитку особистості дитини, створенні психологічно комфортного та безпечного середовища та спрямовані на розумове виховання дітей.

Ураховуючи зазначені вище положення, виокремимо психолого-педагогічні умови розумового виховання дітей, запропоновані В. О. Сухомлинським, які $€$ важливими для професійної діяльності сучасного педагога.

В. О. Сухомлинський передбачав, що чим більший об’єм знань потрібно буде засвоїти дітям, тим більше педагогу необхідно рахуватися 3 природою дитячого організму в період росту, розвитку і становлення особистості [8, с. 16]. Зважаючи на це, першою умовою ми визначаємо врахування закономірностей розумового розвитку особистості, психофізіологічних механізмів мислення людини. Проникливість В. Сухомлинського в психофізіологічні процеси стверджує важливість розуміння педагогами природних закономірностей розвитку дитячого організму. Зокрема, педагог-дослідник зазначав: «Переключення думки, яке є сутністю мислення, можливе лише тоді, коли перед дитиною наочний, реальний або словесний образ... Природа мозку дитини вимагає, щоб іiї розум виховувався... серед наочних образів, щоб думка переключалася з наочного образу на «обробку» інформації про цей образ... [8, с. 31-32]. Цю особливість педагог уважав фундаментальним механізмом мислення.

Другою умовою є врахування педагогами вікових особливостей дітей. Так, Василь Олександрович зазначає: «Думка дитини початкових класів невіддільна від почуттів і переживань. Емоційна насиченість процесу навчання - це вимога, яка висувається законами дитячого мислення» [8, с. 43-44].

Третьою умовою є поетапний розвиток мислення дитини - від образного до абстрактного. У своїх працях педагог відзначає, що «дитина мислить образами. Чим яскравішими вони є, тим глибше вона осмислює закономірності природи». Крім того, В. О. Сухомлинський зауважує, що «образне мислення - обов' язковий етап для переходу до мислення поняттями» [8, с. 133]. Педагог ділиться зі своїми читачами власними професійними надбаннями, розкриваючи свої цілі: «Я намагався, щоб діти оперували такими поняттями, як «явище», «причина», «наслідок», «залежність», «відмінність», «подібність» тощо... Адже ці поняття відіграють велику роль у формуванні абстрактного мислення. Оволодіти цими поняттями неможливо без дослідження живих фактів і явищ, ...без поступового переходу від конкретного предмета, факту, явища до абстрактного узагальнення», - стверджує педагог [8, с. 129].

Четвертою умовою визначаємо створення психологічного комфорту, дотримання культури розумової праці. Неабиякого значення Василь Олександрович надавав дотриманню режиму розумової праці дітей $з$ обов'язковим чергуванням активних періодів із відпочинком або фізичною роботою, почерговій зміні різних видів діяльності.

П'ятою умовою є взаємодія дитини з природою і суспільством, що є основою розумового розвитку дитини. Педагог уважав кожну подорож у природу уроком мислення, уроком розвитку розуму [8, с. 31-32].

Шоста умова - це дослідницький характер розумової праці дітей. Виняткового значення В. О. Сухомлинський надавав дослідницькому характеру розумової праці. Він розумів, що мозок дитини розвивається в процесі встановлення багатогранних зв'язків із предметами та явищами навколишнього світу причинно-наслідкових, часових, функціональних. Тому прагнув допомогти дітям зрозуміти ці зв'язки в явищах навколишнього світу, щоб розвивати їхню допитливість, спостережливість.

Сьомою умовою є виховання особистісних якостей у дітей, які сприятимуть їхньому розумовому розвитку: вміння зосередитися, ставити перед собою цілі, здатність до вольових зусиль, до переборення труднощів. Зокрема, педагог застерігав, що «ні в якому разі не можна допускати, щоб усе давалося дитині легко, щоб вона не знала, що таке труднощі... Виховання волі починається 3 постановки цілі перед самим собою, зосередження розумових сил, осмислення і самоконтролю. Важливо, щоб діти саме в розумовій праці відчули, що таке складно» [8, с. 109]... Він стверджував: «Як мускули розвиваються і укріплюються від фізичних вправ у процесі долання труднощів, так і для формування й розвитку мозку необхідні праця і зусилля».

Восьмою умовою є розвиток пізнавальної мотивації, допитливості дитини. Для цього педагог пропонує дивувати дитину, оскільки «мислення починається зі здивування»; дотримуватися міри в розповіді, давати дитині час на осмислення почутого чи побаченого, залишати щось недоказане, щоб дитині захотілося ще раз повернутися до того, що вона дізналася тощо [8, с. 33, 39].

Дев'ятою умовою є створення інтелектуального середовища. Педагог зазначав, що навчання не повинно зводитися до безперервного накопичення знань, до тренування пам'яті, а має бути «вируючим інтелектуальним життям, яке відбувається в світі гри, казки, краси, музики, фантазії і творчості» [8, с. 75]. Складовими інтелектуального середовища дослідник уважав читання книг, дитячі ігри, створення фантастичних образів, написання мініатюрних творів, бесіди про навколишній світ, вирішення задач на кмітливість, гру в шахи тощо.

Десятою умовою, цінною для осмислення сучасниками, є думка В. О. Сухомлинського щодо призначення школи. Зокрема, він стверджував, що школа насамперед має навчити дитину вчитися, сформувавши в неї необхідні вміння та навички [8, с. 97].

Висновки. Визначені та охарактеризовані нами психолого-педагогічні умови розумового виховання дітей за працями В. О. Сухомлинського спрямовані на врахування закономірностей розумового розвитку особистості, психофізіологічних механізмів мислення людини, вікових особливостей дітей, створення психологічно комфортного інтелектуального середовища, організацію взаємодії дитини з природою і суспільством на основі дослідницької діяльності, а також виховання особистісних якостей у дітей, що сприятимуть їхньому розумовому розвитку. 


\section{СПИСОК ВИКОРИСТАНОЇ ЛІТЕРАТУРИ}

1. Великий тлумачний словник сучасної української мови / уклад. та гол. ред. В. Т. Бусел. Київ = Ірпінь : Перун, 2005. - VIII. -1728 с.

2. Гончаренко С. У. Український педагогічний енциклопедичний словник / С. У. Гончаренко. - Вид. 2-е, доповнене й виправлене. - Рівне : Волинські обереги, 2011. - 552 с.

3. Калініченко Н. Василь Сухомлинський та проблема розумового виховання школярів / Н. Калініченко // Рідна школа. - 2013. - № 8-9. - С. 16-19.

4. Падалка О. С. В. О. Сухомлинський - визнаний у світі педагог і вчений / О. С. Падалка // Свропейські педагогічні студії. - 2013. - Вип. 3-4. - С. 81-102.
5. Савченко О. Я. Дидактика початкової освіти : підруч. для вищ. навч. закл. / О. Я. Савченко. - Вид. 2. К. : Грамота, 2013. - 504 c.

6. Савченко О. Я. Розвиток особистості школяра стрижнева проблема творчості В. О. Сухомлинського / О. Я. Савченко // Освіта. - 2013. - 18-25 верес. - С. 6-7.

7. Сухомлинський В. О. Розмова з молодим директором / В. О. Сухомлинський // Вибрані твори : в 5 т. - К., 1977. - Т. 4. - С. 394-626.

8. Сухомлинский В. А. Сердце отдаю детям / В. А. Сухомлинский. - К. : Рад. шк., 1988. - 272 с.

9. Сухомлинський В. О. Сто порад учителеві / В. О.Сухомлинський//Вибрані твори : в 5 т.-К., 1976.T. 2. - C. 419-654.

Дата надходження до редакиї: 25.06.2019 p.
УДК 37.015.3:[159.922.73:316.613.434]

DOI: 10.37026/2520-6427-2019-99-3-80-86

\section{Олена КОНОНКО,}

докторка психологічних наук, професорка, завідувачка кафедри дошкільної освіти Ніжинського державного університету імені Миколи Гоголя

\section{ДИТЯЧА АГРЕСІЯ: СПЕЦИФІКА, ПРИЧИНИ ВИНИКНЕННЯ, ВИХОВАННЯ ВМІННЯ ЇЇ ДОЛАТИ}

У статті представлено кониептуальний підхід щзодо вивчення агресії як феномена особистісного зростання в ранньому онтогенезі. Розкрито суть та специфіку агресивності в дошкільному дитинстві, зокрема визначено внутрішні та зовнішні чинники ї виникнення як негативної якості особистості. Охарактеризовано зміст поняття "вміння дошкільника долати агресію», розроблено його типологію та сформульовано педагогічні умови ефективного виховання означеного вміння в дітей стариого дошкільного віку.

Ключові слова: агресія, агресивна поведінка, особистісне зростання, внутрішні та зовнішні чинники, вміння долати агресію, педагогічні умови оптимізації виховного процесу.

В статье представлен кониептуальный подход к изучению агрессии как феномена личностного роста в раннем онтогенезе. Раскрыты суть и специфика агрессивности в дошкольном детстве, в частности определены внутренние и внешние факторы ее возникновения как негативного качества личности. Охарактеризовано содержание понятия «умение доикольника преодолевать агрессию», разработана его типология и сформулированы педагогические условия эффективного воспитания определенного умения у детей старшего дошкольного возраста.

Ключевые слова: агрессия, агрессивное поведение, личностный рост, внутренние и внешние факторы, умение преодолевать агрессию, педагогические условия оптимизации воспитательного процесса.
The article substantiates the theoretical and methodological principles of studying aggression as a phenomenon of personal growth; the essence and specificity of aggressiveness in preschool children are revealed; internal and external factors of occurrence of the specified negative quality are determined. Aggression is defined as purposeful destructive behavior of the preschool child, which contradicts the moral norms and inflicts physical harm or causes the victim negative experiences, the state of tension, fear, sadness. The author describes the concept of "ability to overcome aggression» is introduced by the author, the concept of development of a given skill in children of the preschool age is developed through the prism of the subjective approach. Qualifying a child 5-7 years as an active subject of life activity, the ability to overcome aggression is defined as the integral characteristic of the individual, the formation of which is defined by the ability to analyze the situation and their actions, the ability to more or less objectively evaluate the negative effects of aggressive behavior; the ability to make voluntary efforts to curb aggression and overcome negative impulses; the ability to competently and decently make their way out of a conflict situation. These served as criteria for assessing types of aggression curbing in children of preschool age while interacting with their peers. Four types of the investigated skill are distinguished and characterized - constructive, destructive, conformal and contemplative. In the experimental group, only $22.4 \%$ of children have been found to be of constructive type, 